
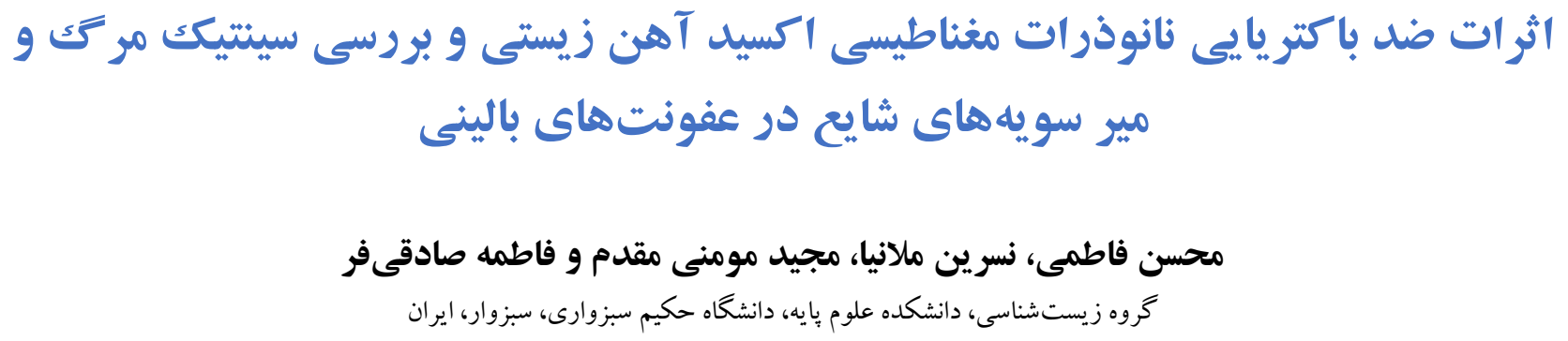

n.mollania@hsu.ac.ir مسئول مكاتبات: نسرين ملانيا،

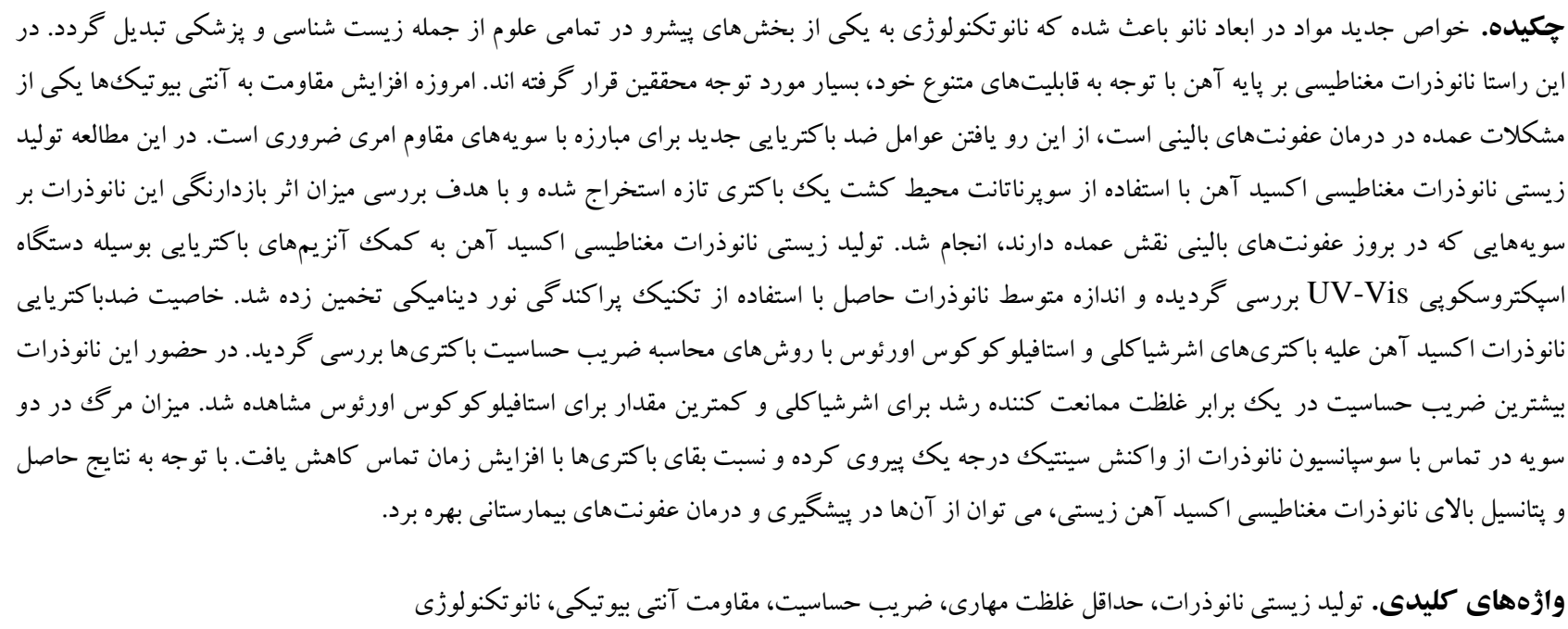

\title{
The anti-bacterial effects of magnetic iron oxide nanoparticles produced by biological method and the kinetic study of mortality of common strains in clinical infections
}

\author{
Mohsen Fatemi, Nasrin Mollania, Madjid Momeni-Moghaddam \& Fatemeh Sadeghifar \\ Department of Biology, Faculty of Basic Sciences, Hakim Sabzevari University, Sabzevar, Iran \\ Corresponding author: Nasrin Mollania, n.mollania@hsu.ac.ir
}

\begin{abstract}
New properties of nano-materials have made nanotechnology the leading part of biology and medical sciences. Due to their various biomedical properties, iron-based magnetic nanoparticles (MNPs) have been highly considered by biological researchers. Nowadays, increasing resistance to antibiotics is a major problem in treating clinical infections. Finding new antibacterial agents is therefore essential for the treatment of resistant strains. In this study, the iron oxide MNPs were produced using culture-medium supernatant of a newly isolated bacterium to investigate the inhibitory effects of the NPs on strains with a major role in clinical infections. Biosynthesis of iron oxide MNPs were detected by UV-Vis spectroscopy and the average size of particles was estimated by dynamic light scattering technique. The anti-bacterial activity of these NPs against E. coli and $S$. aureus was investigated using methods for the calculation of bacterial sensitivity coefficient. In the presence of NPs, the highest sensitivity coefficient value was observed for E. coli in 1xMIC concentration. On the other hand, S. aureus showed the lowest value. The death rate of the two strains in contact with NPs followed the first order kinetic equation and the survival rate decreased with the increase of exposure time. The results of this study as well as the high functionality of iron oxide MNPs, make
\end{abstract}


its application desirable in the prevention and treatment of clinical infections.

Keywords. antibiotic resistance, minimum inhibitory concentration, nanoparticles biosynthesis, nanotechnology, sensitivity coefficient

سرعت مكانيسم مقاومتى خود را توسعه و بهبود بخشند. استفاده كسترده و بيش از حد آنتى بيوتيكها نيز باعث شدت يافتن بروز و كسترش اين مكانيسمهاى مقاومتى در سويههاى مختلف شده است Nasrollahi et al., 2009; Panáček et al., 2009; Seil \& ) Webster, 2012; Thukkaram et al., 2014 كرفتن دانستههاى فوق، يافنن راهها و مواد جديد داراى خاصيت آنتى بيوتيكى براى مقابله با افزايش روزافزون مقاومت عوامل بيمارى زا، امرى حائز اهميت است. استفاده از فلزات به عنوان عوامل ضد عفونى و ضد باكتريايى از دير باز رواج داشته اما با ظهور آنتى بيوتيكهاى مدرن و تركيبى كه اثر بخشى بيشتر و سريع ترى داشتند و نيز با توجه به اثرات جانبى مخرب فلزات و تركيبات حاصل از آنها بروى بافتهاى زنده، براى مدتها اين

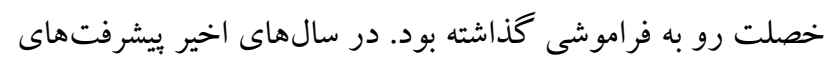
خيره كننده علم نانو و در بيى آن كشف خواص جديد مو اد در ابعاد نانو باعث شد تا محققين كليد مشكل مقاومت روزافزون ميكروار گانيسمهاى بيمارىزا را در نانوذرات فلزى جست و جو كنند. نانوذرات فلزى علاوه بر داشتن خصوصيات شخفت انخيز و بتانسيل بالا در كاربردهاى زيست بزشكى، فاقد اثرات مخرب فلزات و يونهاى حاصل از آنها در ابعاد حجيم، بر سلامت انسان Stoimenov et al., 2002; Thukkaram et al., ) هستند 2014; Ismail et al., 2015 از نظر داشتن خواص ضد باكتريايى و ضد قارجى مورد آزمايش قرار كرفته اند؛ در بررسى اين نانوساختارها همواره بايد اين نكته را مد نظر قرار داد كه برخى فلزات (همجيون مس، روى و نقره) در حالت حجيم نيز خاصيت آنتى ميكروبى از خود بروز مى دهند، حال آنكه برخى ديخر (مانند اكسيد آهن) در حالت حجيم فاقد خاصيت آنتى ميكروبى بوده ولى در بّعد نانو ويزَّى هاى ضد باكتريايى و ضد قارجى از خود بروز مى دهد ) Seil \& Webster, 2012; Arakha et al., 2015 مكانيزم كاملا متفاوت فعاليت ضد باكتريايى نانوذرات نسبت به آنتىبيوتيككهاى مرسوم، نانومواد مى توانند به عنوان جايكزينى
مقام

امروزه نانوتكنولوزى به عنوان شاهراه علوم تحقيقاتى، محل تلاقى حوزههاى مختلفى از علوم در مسير بيشرفت به سوى كشف مرزهاى جديد دانش است. كاهش اندازه ذرات تا مرز نانومتر، تأثيراتى شخرف بر تمام خواص فيزيكى و شيميايى مواد مى كذارد، مسلماً خواص زيستى نيز از اين قاعده مستثنى نبوده و تعاملات دنياى زنده درسطح نانو و با ذراتى در اندازه نانو داراى

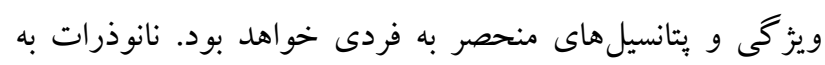
عنوان بايه و نقطه شروع در نانو تكنولوزى، لازمه ى تمام تحقيقات و بثزوهشهاى اين حوزه هستند و از اين رو روش هاى توليد و سنتز آنها از اهميت ويزه اى برخوردار است. نانوذرات مغناطيسى اكسيد آهن از جمله نانوساختارهاى جذاب در عرصه زيست يزشكى هستند كه با توجه به قابليت اصلاح سطح، زيست ساز كارى، يايدارى بالا و همجنين خاصيت مغناطيسى در كنار ساير

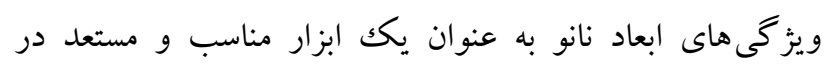

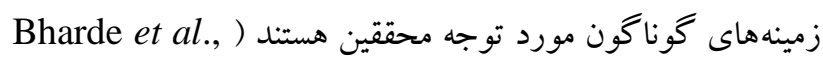
2006; Bhabra et al., 2009; Hulkoti \& Taranath, 2014). سنتز سبز ذرات در ابعاد نانو، از زمره روشهاى يايين به

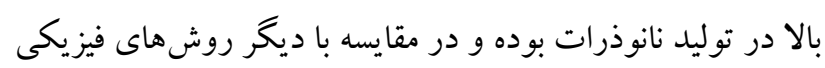
و شيميايى از مزاياى قابل توجهى برخوردار است. روشهاى سنتز

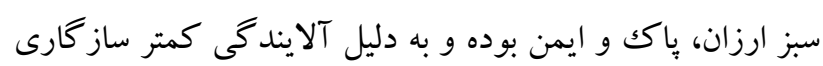
Bharde et al., 2005; Bharde ) بيشترى با محيط زيست دارند .et al., 2006; Lloyd et al., 2011 در سالهاى اخير افزايش مقاومت عوامل عفونى باكتريايى نسبت

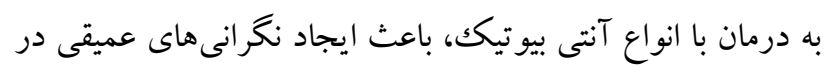

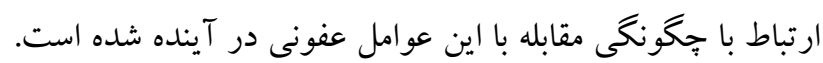
كزارشات رسمى حاكى از افزايش ميزان ابتلا به عفونت با سويه هاى فوق مقاوم و مرگك و مير ناشى از آنها در دهه اخير است ز Nel et al., 2009; Seil \& Webster, 2012) طريق مكانيسمهاى متعددى نسبت به آنتى بيوتيككها مقاومت بيدا مى كنند، آنها با داشتن سرعت توليد مثل بالا قادرند در صورت زنده ماندن حتى يكك كلنى كوجىك در حضور آنتى بيوتيك، به 


\section{سنتز زيستى نانوذرات مغناطيسى اكسيد آهن}

نانوذرات مغناطيسى اكسيد آهن با استفاده از سويرناتانت محيط آنا

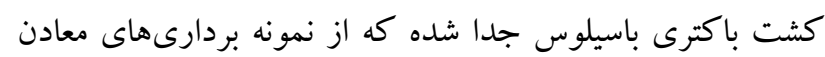

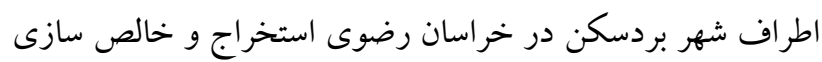

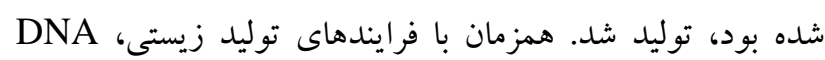

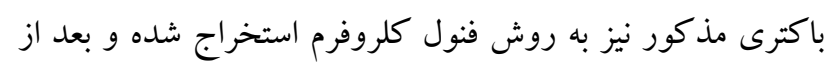

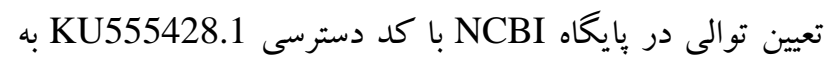
ثبت رسيد. باكترى مذكور در محيط كشت استاندارد نوترينت

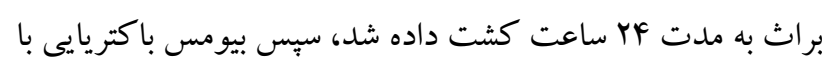

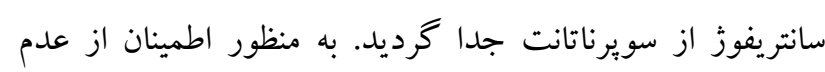

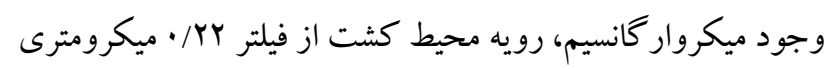

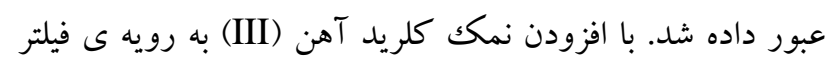
شده، تغيير رنغك و افزايش كدورت محلول و در بيى آن تشكيل رسوبات قهوه اى رنغك مشاهده گرديد. حضور نانوذرات اكسيد

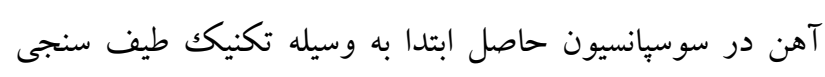
UV-Vis

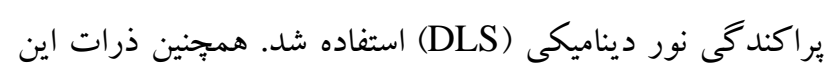

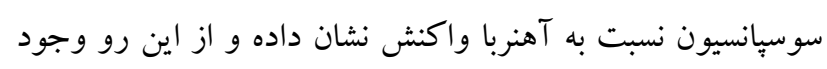
خاصيت مغناطيسى در آنها مسجل گر ديد. آناليز يراكند آنى نور ديناميكى براكندگى نور ديناميكى يكك روش فيزيكى براى تعيين توزيع دوريك

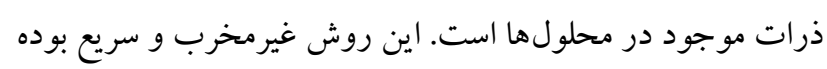

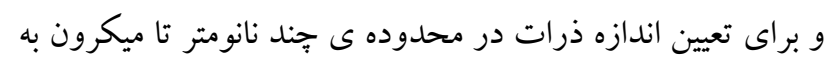
كار مى رود. اين روش به برهمكنش نور با ذره بستخى داشته و نور

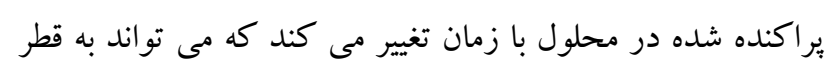

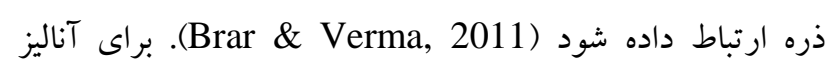
أ DLS از تغليظ با روتارى استفاده كرديم. محلول حاوى نانوذره درون

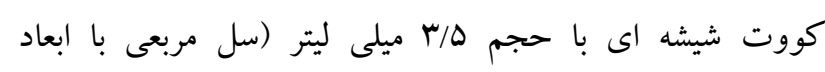

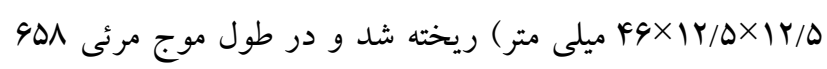

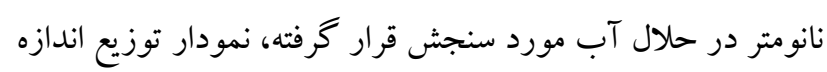
نانوذرات به دست آمد. نمونه هاى باكتريايى جهت انجام آزمايشات ضد باكتريائ انيى از ياكترىهاى اشرشياكلى (ATCC (ATCC 25922) و استافيلو كو كوس اورئوس (ATCC 25923) استفاده شد كه به صورت ليوفيليزه نخهدارى شده و از آزمايشگاه
مطلوب و با يتانسيل بالا مورد بررسى و استفاده قرار گيرند. تا كنون

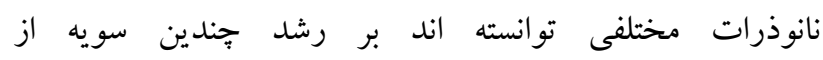

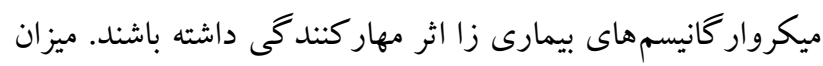

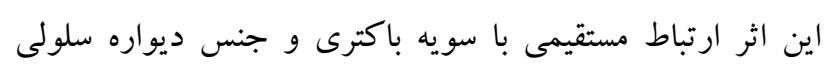

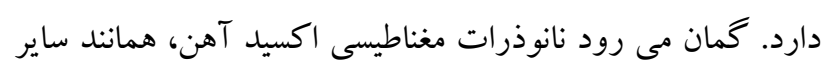
نانوذرات اكسيدهاى فلزى، از طريق ميان كنشهاى الكترواستاتيك ماتك

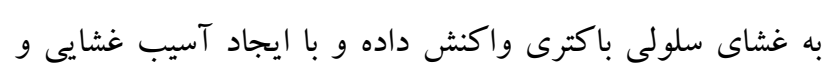

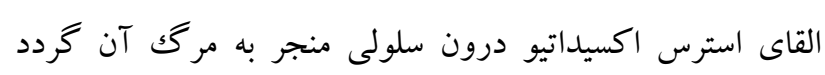
(Tran et al., 2010; Ismail et al., 2015) در اين بثزوهش اثر ضد باكتريايى نانوذرات مغناطيسى اكسيد

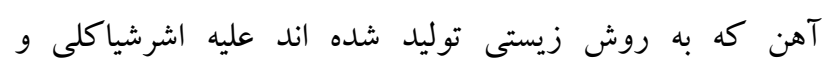

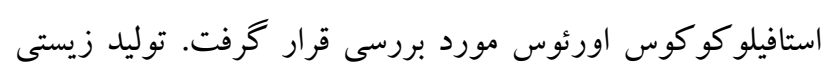

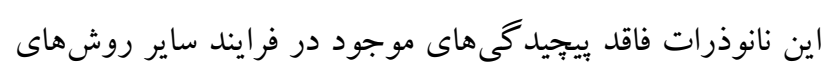

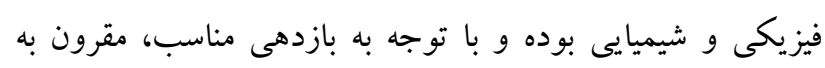

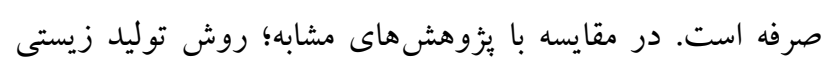

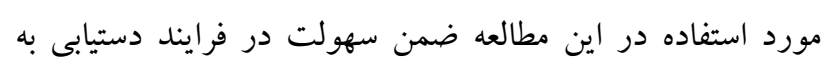
نانوذرات، از دو مزيت زمان كوتاه و بازدهى قابل توجه در ميزان

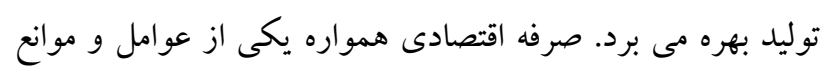

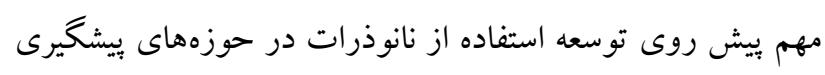

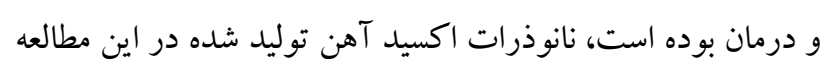

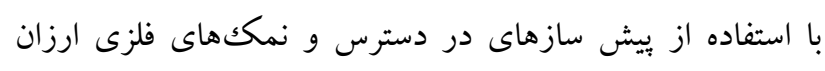

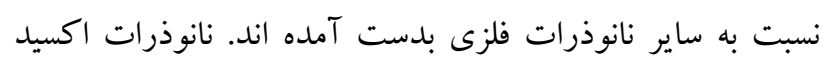

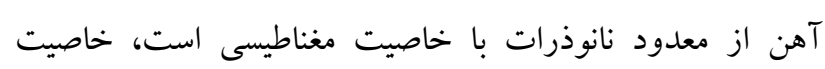

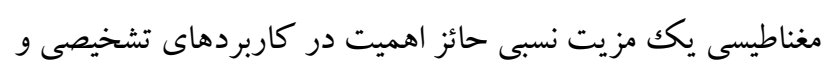

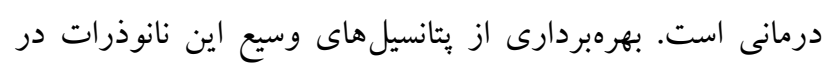

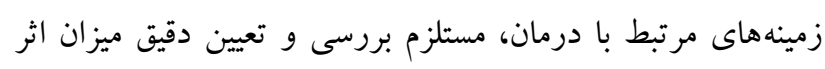

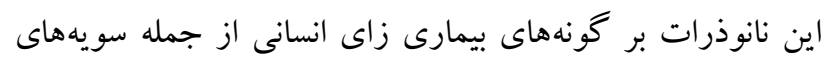
شايع در عفونتهاى بالينى است. در اين مطالعه با ضمن تعيين ميزان

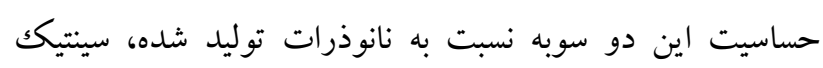

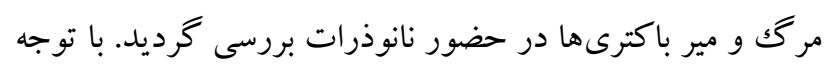

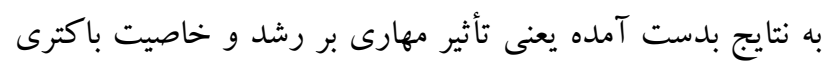

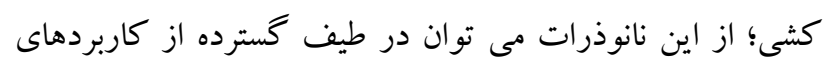

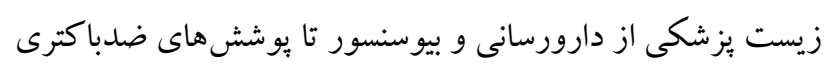

$$
\text { براى سطوح و ابزارها بهره برد. }
$$

مواد و روشها 
لوله به ترتيب سير نزولى دارند). سبس لوله هاى حاوى نانو ذرات و

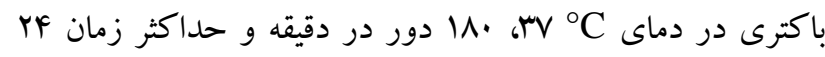
ساعت گرما گذارى شدند. در همه محيطها از سوسيانسيون باكتريايى با كدورت نيم مكك فارلند استفاده شد.

آزمايشات مطالعه سينتيك مركى باكترىهاى بيمارىزا و تعيين مقدار حساسيت آنها به نانو ذرات مغناطيسى اكسيد مآهن

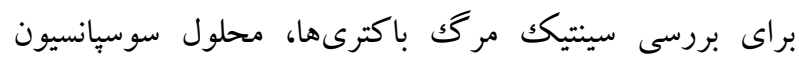

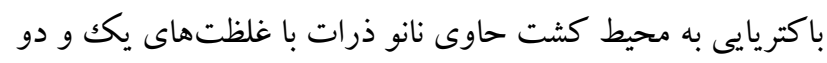

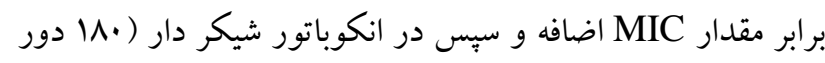

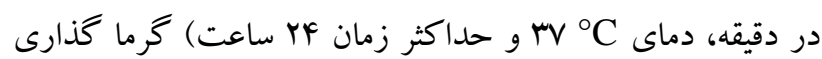
شدند. در زمانهاى مورد نظر (صفر تا هاعت) از سوسيانسيون

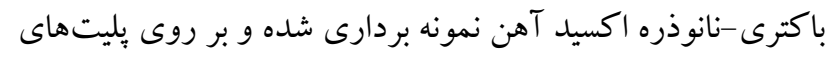

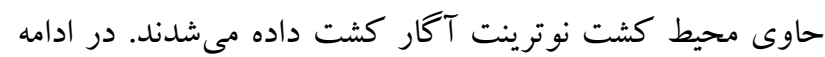
كلنىهاى شكل گرفته براى هر زمان و هر باكترى در هر غلظت

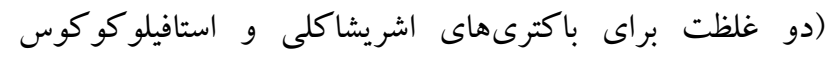

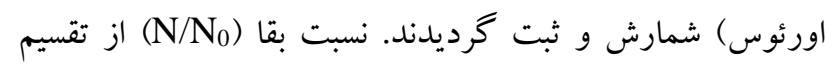
تعداد كلنىهاى باكترى در زمان نمونه بردارى (N) بر تعداد

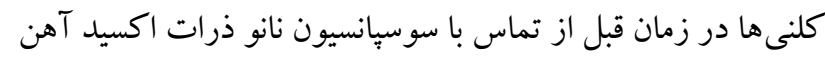

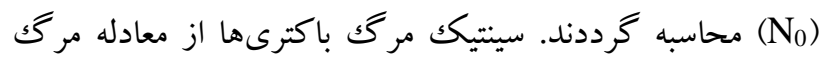

درجه اول تبعيت مىنمايند. معادله سينتيكك به صورت زيت مردير است:

$$
\frac{d N}{d t}=-k
$$

در معادله بالا (k) بيان كننده ثابت ميزان مرگك و ميردرجه اول،

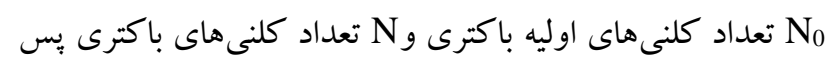

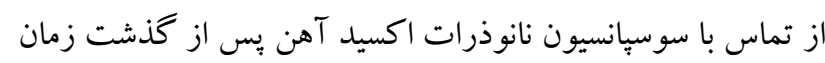

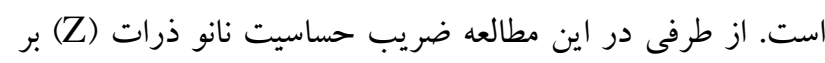

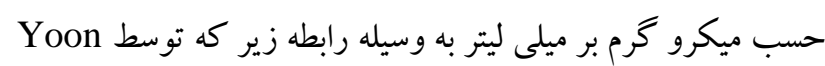

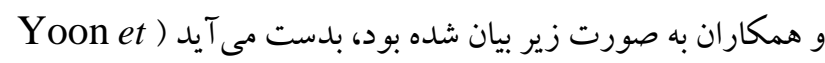
:(al., 2007

$$
Z=\frac{-\ln \left(\frac{N}{N_{0}}\right)}{C}
$$

در رابطه بالا N تعداد كلنىهاى باكتريايى پس از تماس با نانوذرات اكسيد آهن، No تعداد كلنىهاى باكتريايى اوليه و غلظت نانوذرات مورد مطالعه بر حسب ميكروگرم بر ميلى ليتر
ميكروبيولوزى بزشكى تهيه شده بودند. با توجه به اينكه احتمالا

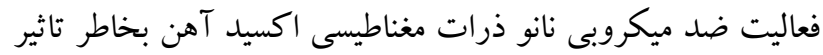

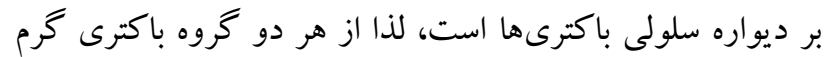

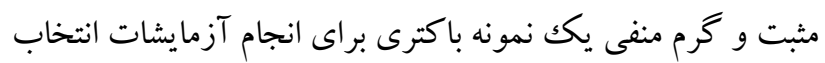
شدند. به منظور تهيه سوسيانسيون باكتريايى جهت انجام آزمايش -

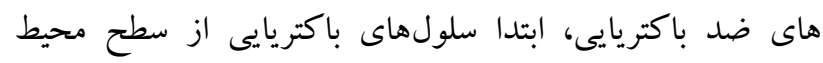
كشت به كمك لوب استريل جمع آورى و در يكك ميلى ليتر بافر

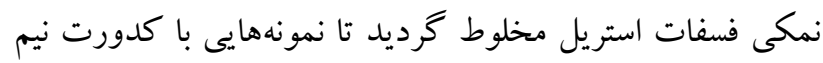

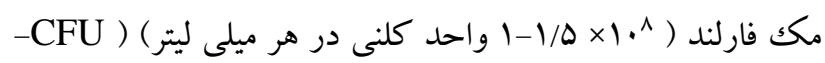
واحد تشكيل كلنى) تهيه شود. براى اطمينان، جذب محلول آماده

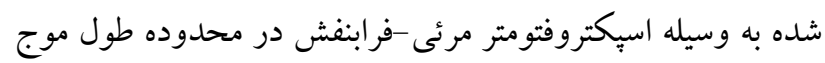

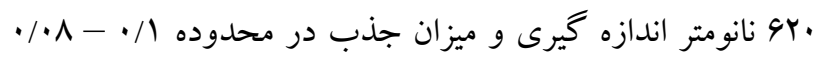

$$
\text { تنظيم گرديد. }
$$

\section{آزمون ضد باكتريايى نانوذرات مغناطيسى اكسيد آهن}

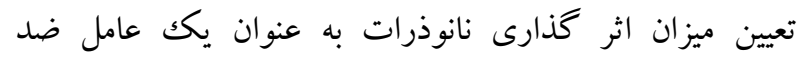
ميكروبى؛ نيازمند روش هاى آزمايشكاهى است كه از طريق آنها

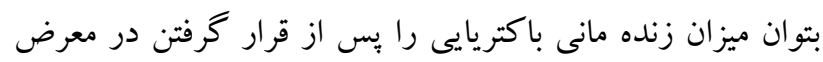

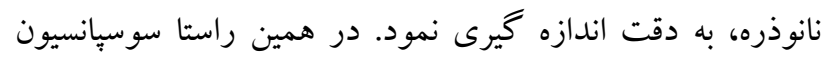

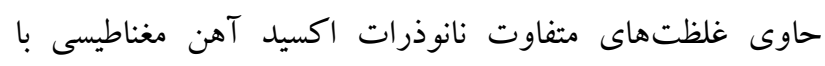

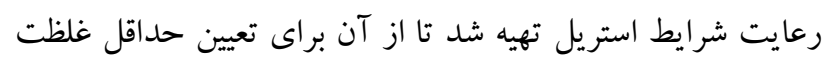

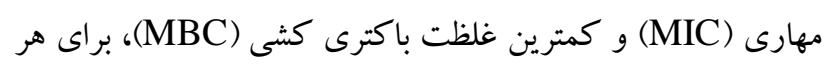

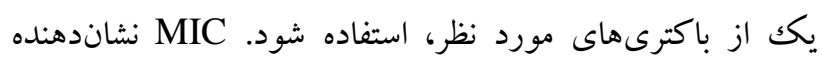

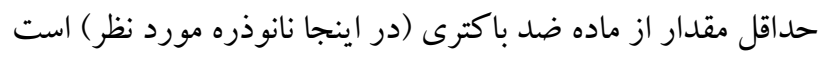

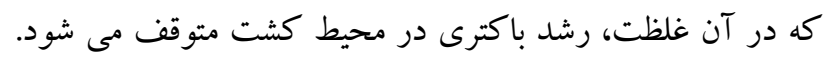

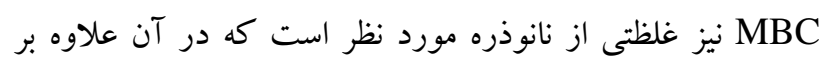

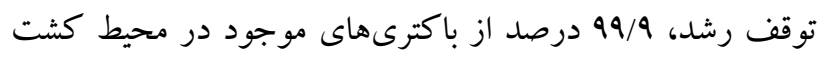

$$
\text { نيز از بين مىروند. }
$$

در اين راستا از با لوله كه هر كدام حاوى Y ميلى ليتر محيط

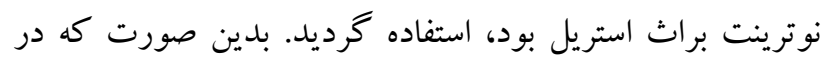

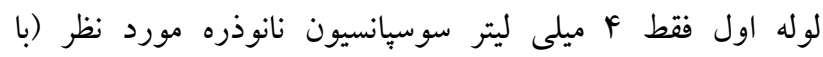

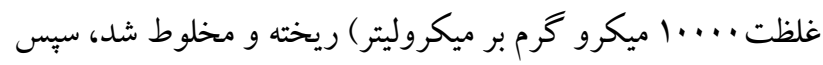

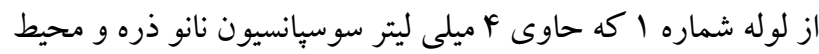

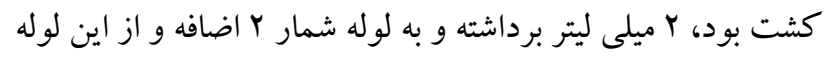

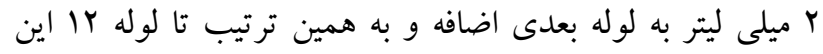

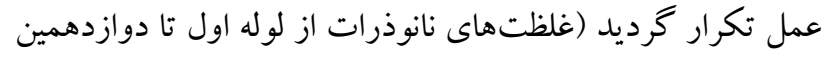


آزمايش انجام شده در اين بثزوهش، بيك شاخص در طول موج هاب نانومتر مشاهده شد (شكل (). دادههاى حاصل از آناليز DLS نيز نشان داد كه سوسبانسيون حاصل، حاوى ذراتى با قطر متوسط

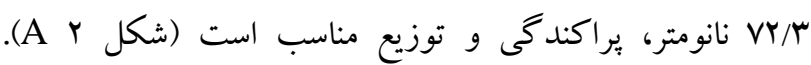
همجنين مشاهده كرديد با افزايش pH سويرناتانت ييش از تلقيح نمكك به سويرناتانت، قطر متوسط ذرات توليد شده تا ب/•ه نانومتر

$$
\text { كاهش مى يابد (شكل r P r). }
$$

خاصيت ضد باكتريايى نانوذرات اكسيد آهن توليد شده به اين روش مى تواند به عنوان يكك ويز گى ذاتى و بدون نياز به اصلاح سطح، مطرح شده و ارزيابى كردد. بر اساس نتايج بدست آمده از بررسى فعاليت ضد ميكروبى، مقدار MIC براى باكترى اشرشيا كلى و استافيلو كو كوس اورئوس نسبت به نانو ذره آهن به ترتيب ها و .19 ميكرو أرم بر ميلى ليتر محاسبه شد. نتايج تعيين مقدار نشان داد كه اشرشياكلى نسبت به استافيلو كو كوس اورئوس از حساسيت بيشترى برخوردار بوده است و نسبت به نانو ذرات توليد شده كمتر مقاومت دارد. مقدار ضريب حساسيت براى هر : يكى از باكترىها و سوسيانسيون نانوذرات و براى هر بازه زمانى نمونه بردارى محاسبه گرديد. ميانخين ضريب حساسيت باكترىها نسبت به نانوذرات مورد استفاده در اين مطالعه در جدول آ آورده شده است. همان كونه كه در جدول ا نشان داده شده است، مقدار ضريب حساسيت S. aureus براى نانوذره اكسيد آهن با افزايش
است. با استفاده از مقادير Z و C، نسبت باكترىهاى زنده (N/No) قابل بيش بينى است. مقدار بالاى Z به اين معنى است كه باكترىها نسبت به نانوذرات اكسيد آهن از حساسيت بيشترى برخوردار بوده و به عبارت ديخر بيانكر اين است كه نانو ذرات اكسيد آهن داراى خاصيت ضد باكتريايى بيشترى است.

مطابق روش مطرح شده در بخش روشها، نمك آهن (III) كلريد 4 آبه به مقدارى كه غلظت آن در حجم مورد نظر از سويرناتانت به mM ه برسد، اضافه شد. با افزودن محلول نمكك،

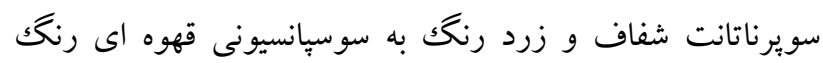
تبديل شده، بعد از ·م دقيقه طيف جذبى آن نسبت به سويرناتانت فاقد نمكك توسط دستگاه اسپكتروسكويى UV-Vis خوانده شد. بنا به گزارشات منتشر شده در مقالات و منابع معتبر محدوده وسيعى براى ييكك نانوذرات اكسيد آهن ذكر شده كه بسته به اندازه ذرات، روش توليد و نوع يوشش سطحى مى تواند تا حدود زيادى متفاوت

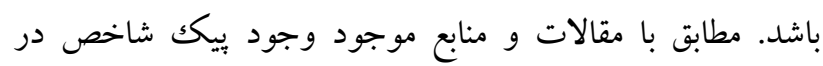

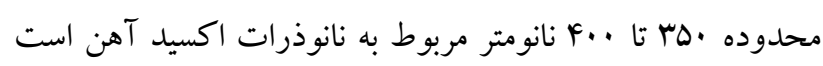
(Makarov et al., 2014). جابجايى ييك سويرناتانت تلقيح شده با نمكك نسبت به محلول آبى نمك و نيز محلول محيط كشت و نمكك؛ نشان دهنده توليد نانوذرات اكسيد آهن است. در شرايط

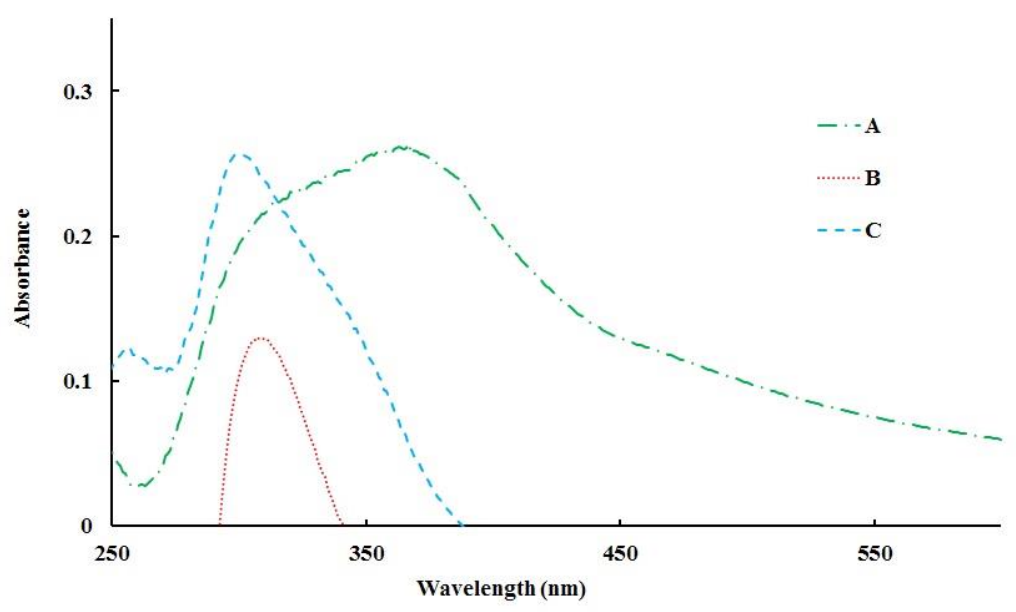

شكل 1- طيف جذبى UV-Vis نانوذرات مغناطيسى اكسيد آهن توليد شده به روش زيستى. A. طيف جذبى سويرناتانت حاوى نانوذرات توليد شده (سويرناتانت+

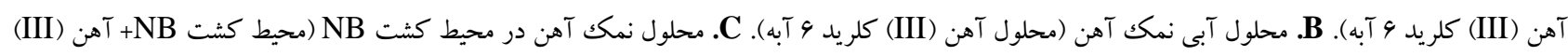
كلريد 4 آبه).

Fig. 1. UV-Vis absorption spectra of biosynthesized iron oxide MNPs. A. absorption spectra of supernatant containing produced NPs (Supernatant $+\mathrm{FeCl}_{3} .6 \mathrm{H}_{2} \mathrm{O}$ ). B. aqueous solution of iron salt $\left(\mathrm{FeCl}_{3} \cdot 6 \mathrm{H}_{2} \mathrm{O}\right.$ solution). $\mathbf{C}$. iron salt solution in nutrient broth medium $\left(\mathrm{NB}+\mathrm{FeCl}_{3} \cdot 6 \mathrm{H}_{2} \mathrm{O}\right)$. 

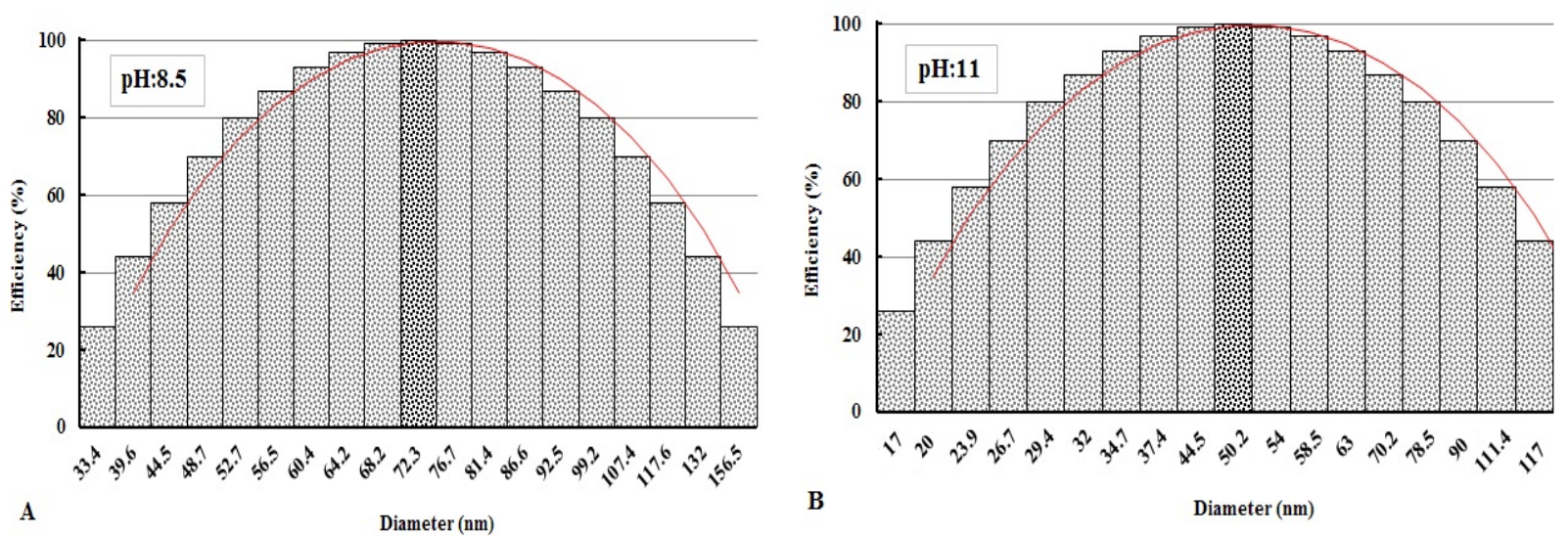

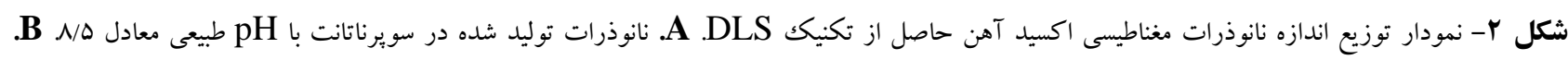

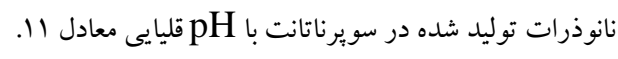

Fig. 2. Size distribution diagram of biosynthesized iron oxide NPs by DLS technique. A. Produced NPs in natural supernatant with $\mathrm{pH}$ equal to 8.5. B. Produced NPs in alkaline supernatant with $\mathrm{pH}$ equal to 11.

$$
\text { جدول ا- ميانكين مقادير ضريب حساسيتهاى بدست آمده براى هر يك از باكترى ها در حضور نانو ذرات مغناطيسى اكسيد آهن. }
$$

\begin{tabular}{|c|c|c|c|}
\hline Escherichia coli & Staphylococcus aureus & 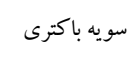 & \\
\hline$\cdots \Delta \phi$ & 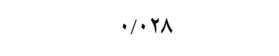 & & يك برابر غلظت ممانعت كتنده رشد (1xMIC) (pg/ml) \\
\hline...$+q$ & $1 . \pi$ & & دو برابر غلظت ممانعت كتنده رشد (2xMIC) (بg/ml) \\
\hline
\end{tabular}

Table 1. The sensitivity coefficient mean values obtained for each of the bacteria in contact with iron oxide NPs.

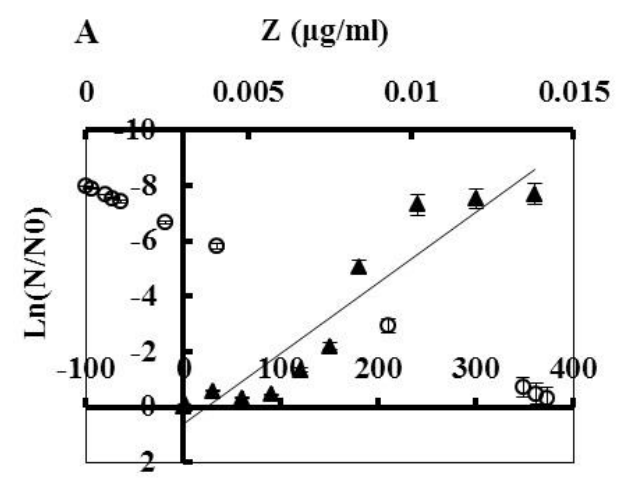

Time(min)

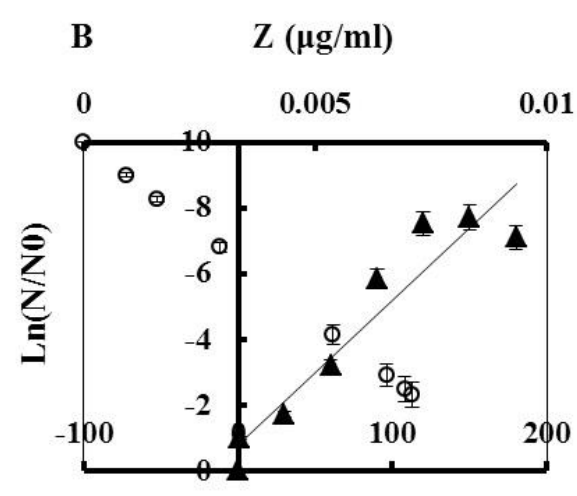

Time(min)

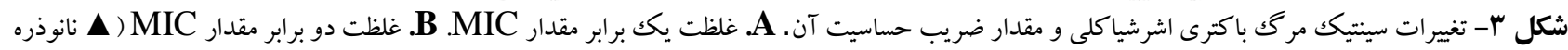

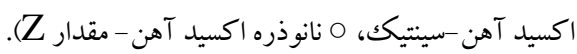

Fig. 3. The variation of E. coli mortality kinetics and its sensitivity coefficient. A. Concentration equal to the amount of MIC. B. Concentration twice the amount of MIC. ( $\Delta$ Iron oxide NP-kinetics, Iron oxide NP-Z value). 


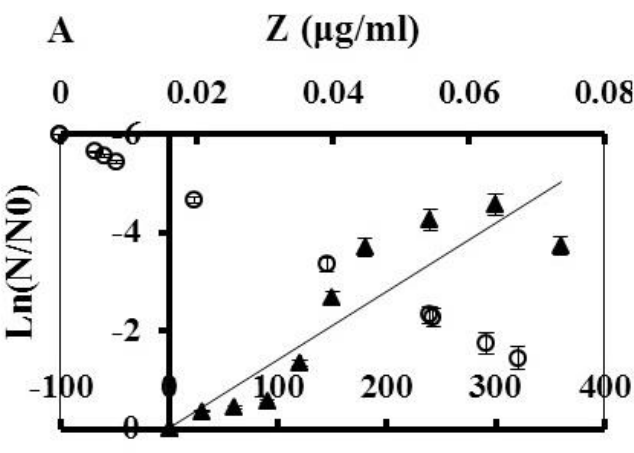

Time(min)

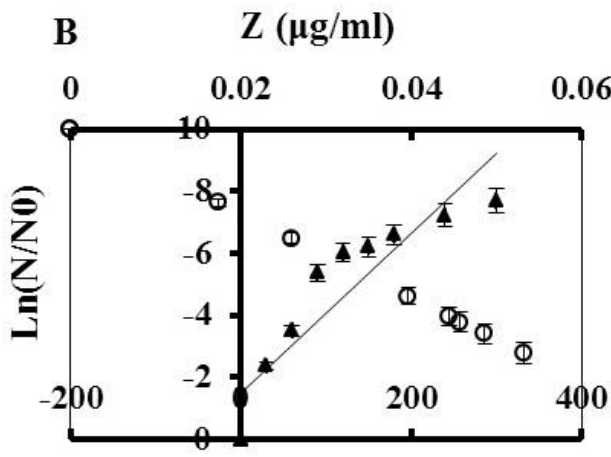

Time(min)

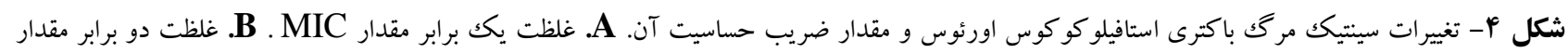
MIC

Fig. 4. The variation of $S$. aureus mortality kinetics and its sensitivity coefficient. A. Concentration equal to the amount of MIC. B. Concentration twice the amount of MIC. ( $\Delta$ Iron oxide NP-kinetics, ○ Iron oxide NP-Z value).

نتايج حاصل از اين يزوهش به وضوح نشاندهنده خصلت ضد

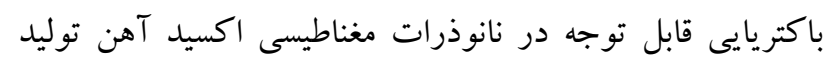

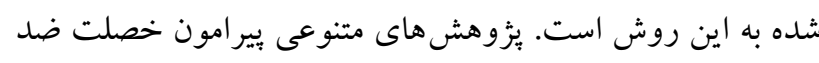

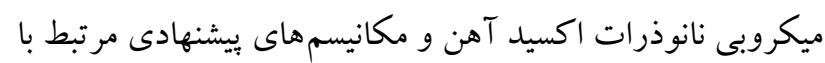

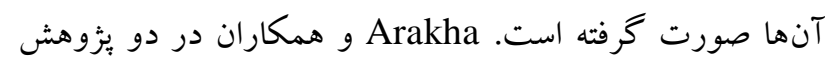
مجزا ضمن بررسى جامع مكانيسم ضد ميكروبى نانوذرات اكسيد

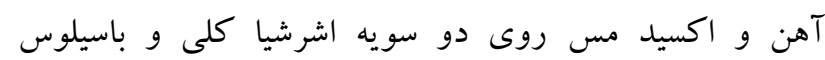

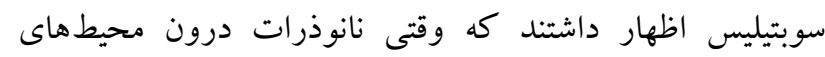

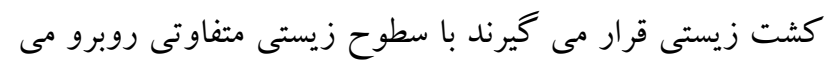

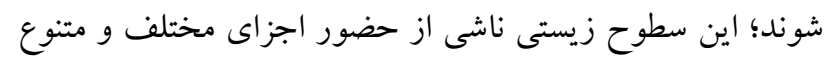

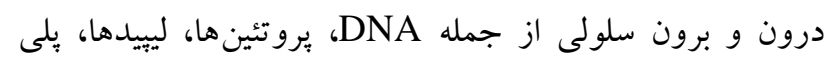

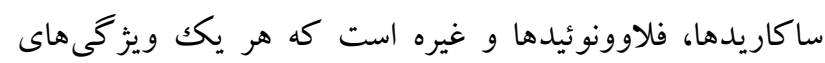

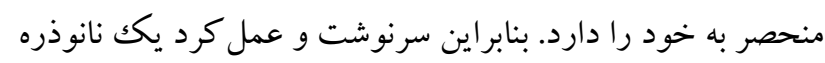

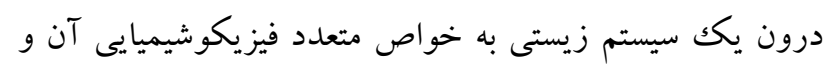
متعاقباً ميان كنشهاى ايجاد شده با سطوح زيستى بستخى دارد.

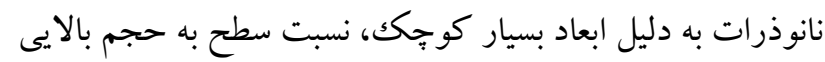

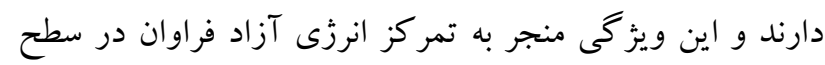

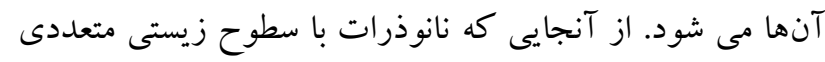

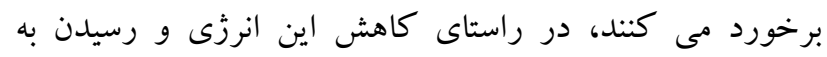

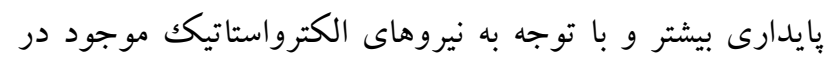

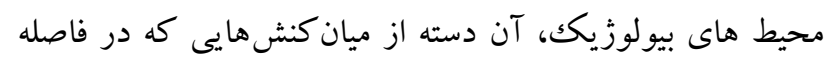
مناسب بتوانند بر سد انرزى نانوذره فائق آيند؛ باعث ايجاد جنت
غلظت نانوذرات از يكك برابر مقدار MIC به دو برابر MIC، افزايش

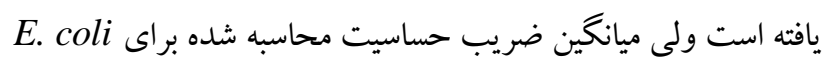
در برابر نانوذرات اكسيد آهن با افزايش غلظت مئ (از يكك برابر مقدار

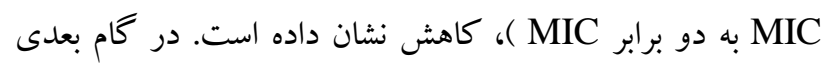

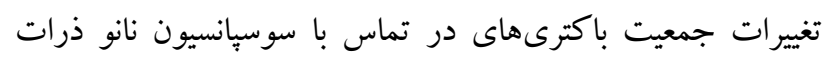
نسبت به زمان تماس آنها و در نتيجه سينتيك مركى آنها محاسبه

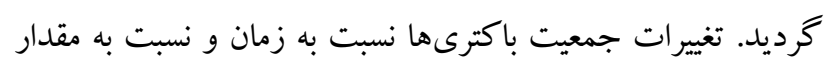

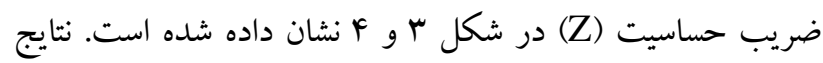
بررسى سينتيك مركى باكترىها نشان داد نسبت بقا با افزايش غلظت

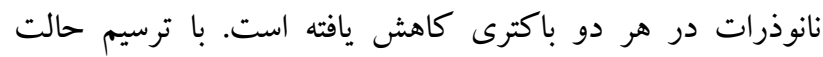

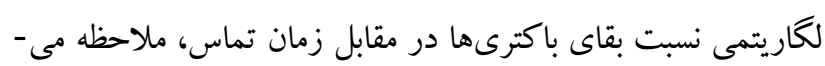

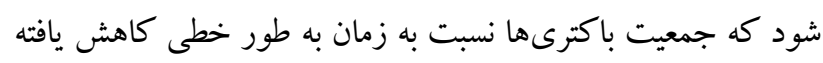
است. از سوى ديخر همانطور كه در شكل B F F مشاهده مى شوده،

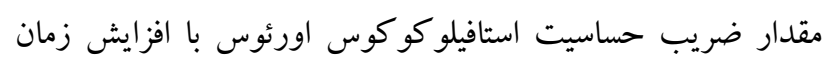
تماس و مقدار نانوذره، افزايش نشان داده است.

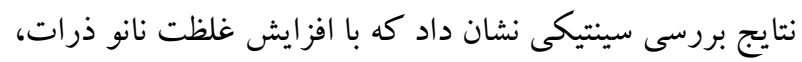

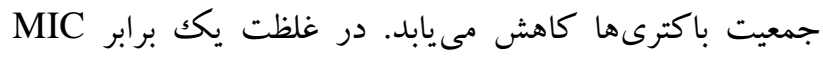
رشد مجدد باكترىها وجود داشت اما با افزايش غلظت به مقدار دو برابر MIC، پِ از كاهش جمعيت باكترىها، رشد مجدد آنها وجود ندارد. 
هنگاميكه نسبت لكاريتمى زنده ماندن باكترىها به زمان داراى

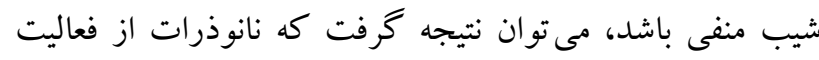

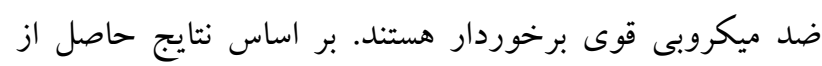

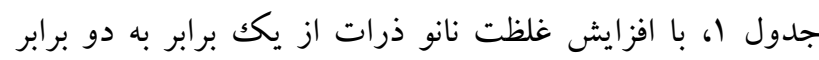

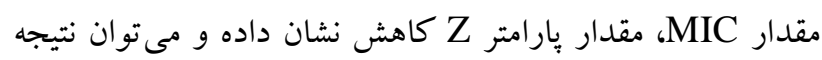

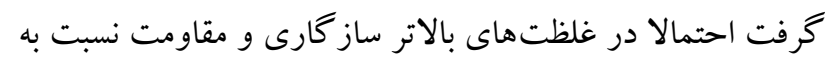

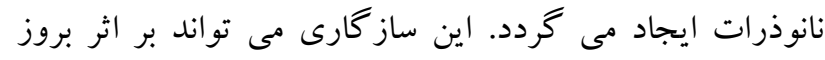

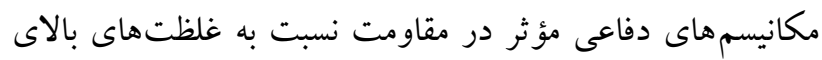

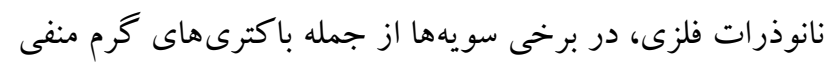

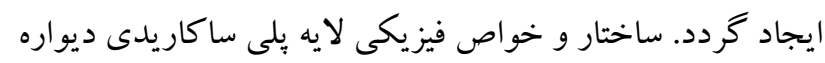

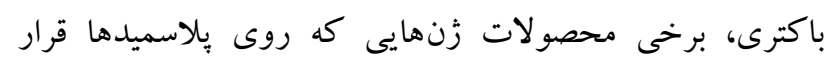
كرفته اند (و در جهت كاهش اثرات استرس اكسيداتيو ايجاد شده

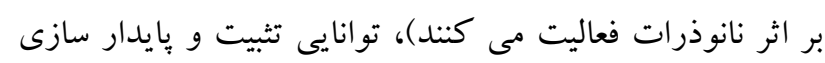

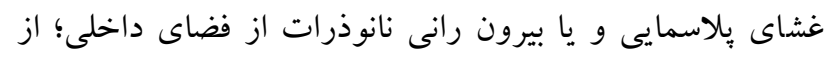

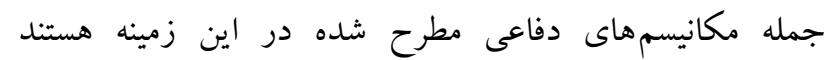

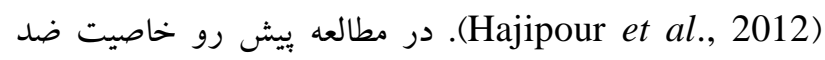
باكتريايى نانو ذرات اكسيد آهن عليه باكترىهاى استافيلو -

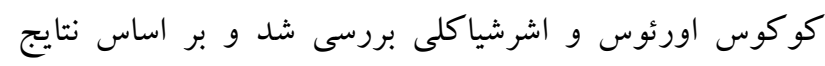

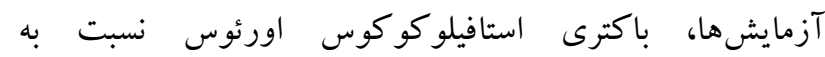

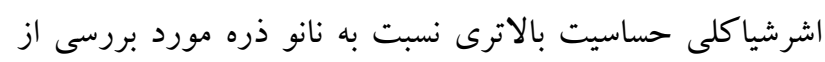

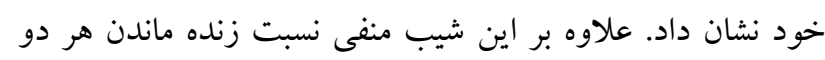

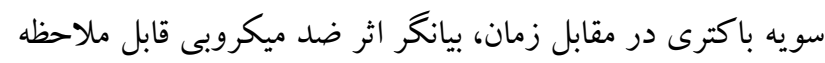

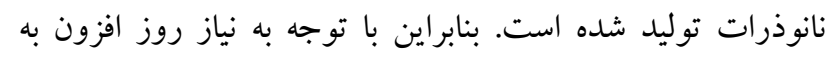

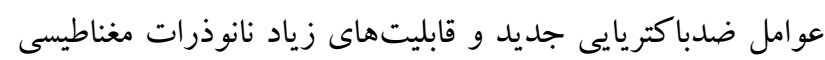

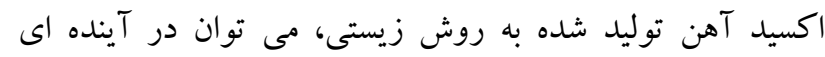

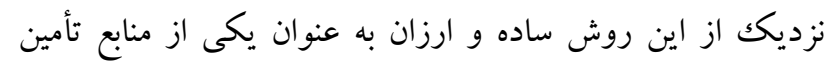

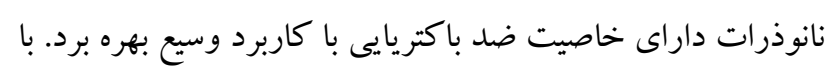

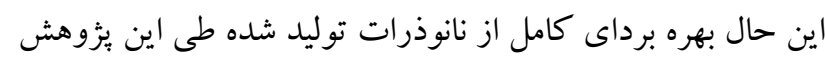

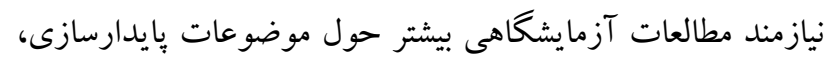

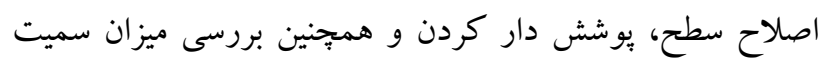

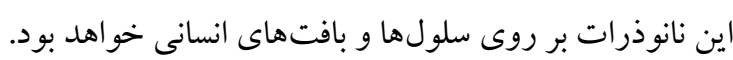

\section{سياستز ارى}

اين مقاله حاصل پايان نامه كارشناسى ارشد در رشته بيوشيمى

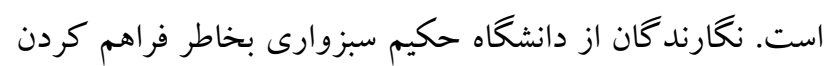
امكانات آزمايشگاهى در انجام اين تحقيق قدردانى كنند.
الكترون-حفره يا همان الكترون آزاد مى شوند. الكترون آزاد درون سيستمهاى زيستى به توليد گونهاى آزاد اكسيرن فعال

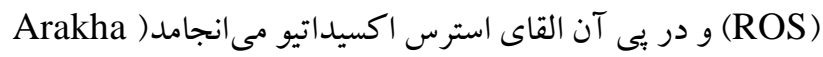
.et al., 2015 از مجموع اين مطالعه و ساير يثزوهشها مى توان دريافت كه در

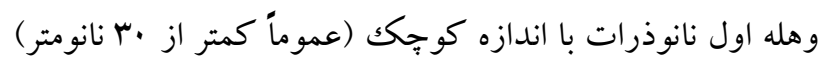
بواسطه نفوذ به درون غشاى سلولى و ايجاد تداخل در فرايندهاى

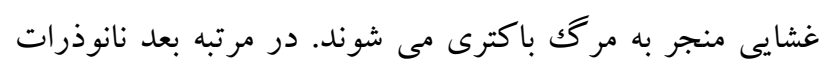

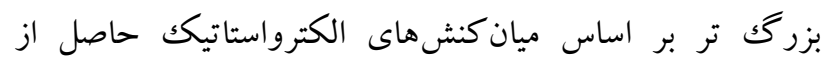
يتانسيل زتاى مثبت سطح نانوذره و بار سطحى منفى ديواره

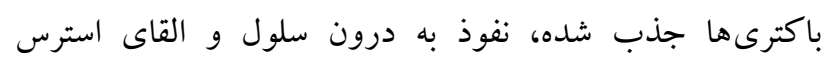

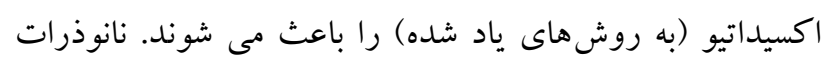

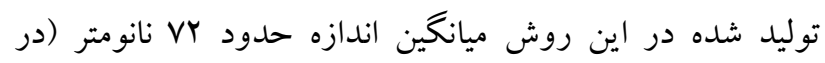
و و pH:N/ه اثر گذارى از طريق مكانيسم دوم محتمل تر است. هرجند از از آنجا

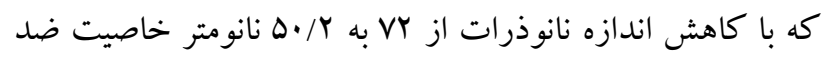

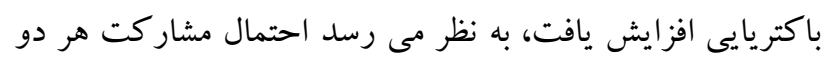

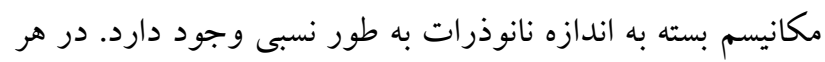
صورت مى توان كفت ايجاد استرس اكسيداتيو بر اثر تشكيل

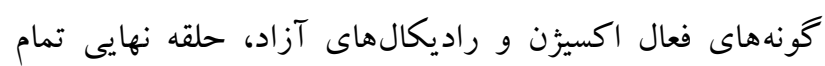

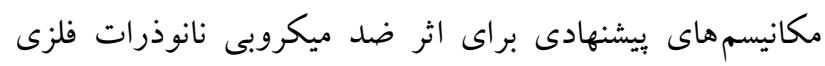

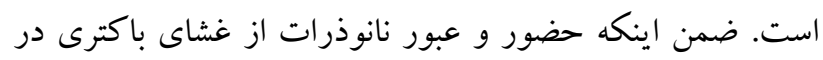

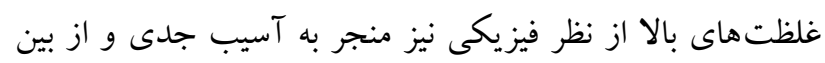

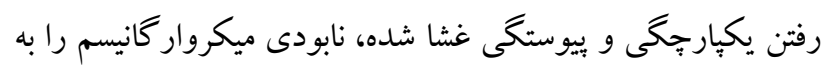
Seil \& Webster, 2012; Thukkaram et ) همر خو اهد داش ميخت مخصهم 2014

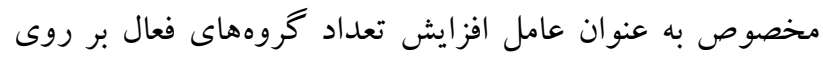

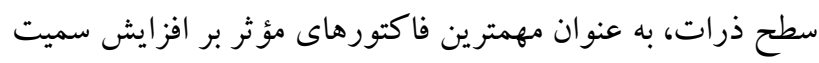

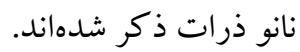
با در نظر گرفتن نتايج حاصل از اين مطالعه مشاهده مى شودا؛

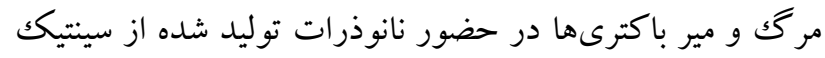

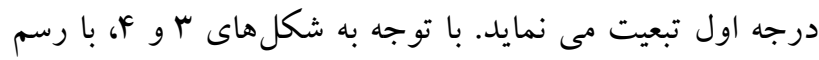

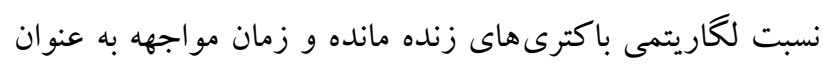

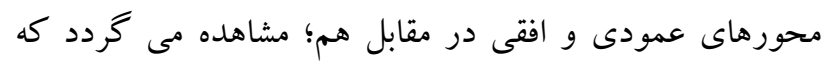
جمعيت هر دو سويه باكتريايى به صورت خطى كمودى كاهش معى يابد. 


\section{REFERENCES}

Arakha, M., Pal, S., Samantarrai, D., Panigrahi, T.K., Mallick, B.C., Pramanik, K., Mallick, B. and Jha, S. 2015. Antimicrobial activity of iron oxide nanoparticle upon modulation of nanopar-ticlebacteria interface. - Sci. Rep. 5: 1-12.

Bhabra, G., Sood, A., Fisher, B., Cartwright, L., Saunders, M., Evans, W.H., Surprenant, A., LopezCastejon, G., Mann, S., Davis, S.A., Hails, L.A., Ingham, E., Verkade, P., Lane, J., Heesom, K., Newson, R. and Case, C.P. 2009. Nanoparticles can cause DNA damage across a cellular barrier. - Nat. Nanotechnol. 4: 876-883.

Bharde, A., Rautaray, D., Bansal, V., Ahmad, A., Sarkar, I., Yusuf , S.M., Sanyal, M. and Sastry, M. 2006. Extracellular biosynthesis of magnetite using fungi. Small. 2: 135-141.

Bharde, A., Wani, A., Shouche, Y., Joy, P.A., Prasad, B.L.V. and Sastry, M. 2005. Bacterial aerobic synthesis of nanocrystalline magnetite. - J. Am. Chem. Soc. 127: 9326-9327.

Brar, S. K. and Verma, M. 2011. Measurement of nanoparticles by light-scattering techniques. - Trends Anal. Chem. 30: 4-17.

Hajipour, M.J., Fromm, K.M., Ashkarran, A.A., Aberasturi, D.J. De, Larramendi I.R. De, Rojo, T., Serpooshan, V., Parak, W.J. and Mahmoudi, M. 2012. Antibacterial properties of nanoparticles. Trends Biotechnol. 30: 499-511.

Hulkoti, N.I. and Taranath, T.C. 2014. Biosynthesis of nanoparticles using microbes- a review. - Colloids Surf. B Biointerfaces 121: 474-83.

Ismail, R. A., Sulaiman, G.M., Abdulrahman, S. A. and Marzoog, T.R. 2015. Antibacterial activity of magnetic iron oxide nanoparticles synthesized by laser ablation in liquid. - Mater. Sci. Eng. C Mater. Biol. Appl. 53: 286-297.

LIoyd, J.R., Byrne, J.M. and Coker, V.S. 2011. Biotechnological synthesis of functional nanomaterials. - Curr. Opin. Biotechnol. 22: 509-515.
Makarov, V.V., Makarova, S.S., Love, A.J., Sinit-syna, O.V., Dudnik, A.O., Yaminsky, I.V., Taliansky, M.E. and Kalinina, N.O. 2014. Biosynthesis of stable iron oxide nanoparticles in aqueous extracts of Hordeum vulgare and Rumex acetosa Plants. - Langmuir. 30: 5982-5988.

Nasrollahi, Y.K., Kim, B.H. and Jung, G. 2009. Antifungal activity of silver nanoparticles on some fungi. - Plant Dis. 93: 1037-1043.

Nel, A.E., Mädler, L., Velegol, D., Xia, T., Hoek, E.M. V., Somasundaran, P., Klaessig, F., Castranova, V. and Thompson, M. 2009. Understanding biophysicochemical interactions at the nano-bio interface. - Nat. Mater. 8: 543-557.

Panáček, A., Kolářr, M., Večeřová, R., Prucek, R., Soukupová, J., Kryštof, V., Hamal, P., Zbořil, R. and Kvítek, L. 2009. Antifungal activity of silver nanoparticles against Candida spp. - Biomat-erials. 30: 6333-6340.

Seil, J.T. and Webster, T.J. 2012. Antimicrobia applications of nanotechnology: methods and literature. - Int. J. Nanomedicine. 7: 2767-2781.

Stoimenov, P.K., Klinger, R.L., Marchin, G.L. and Klabunde, K.J. 2002. Metal oxide nanoparticles as bactericidal agents. pdf. - Langmuir. pp 6679-6686.

Thukkaram, M., Sitaram, S., Kannaiyan, S.K. and Subbiahdoss, G. 2014. Antibacterial efficacy of ironoxide nanoparticles against biofilms on different biomaterial surfaces. - Int. J. Biomater. 2014:1-6.

Tran, N., Mir, A., Mallik, D., Sinha, A., Nayar, S. and Webster, T.J. 2010. Bactericidal effect of iron oxide nanoparticles on Staphylococcus aureus. - Int. J. Nanomedicine 5: 277-283.

Yoon, K.Y., Byeon, J.H., Park, J.H. and Hwang, J. 2007. Susceptibility constants of Escherichia coli and Bacillus subtilis to silver and copper nanopar-ticles. Sci. Total Environ. 373: 572-575.

How to cite this article:

Fatemi, M., Mollania, N., Momeni-Moghaddam, M. and Sadeghifar, F. 2019. The anti-bacterial effects of magnetic iron oxide nanoparticles produced by biological method and the kinetic study of mortality of common strains in clinical infections. - Nova Biol. Reperta 6: 30-38.

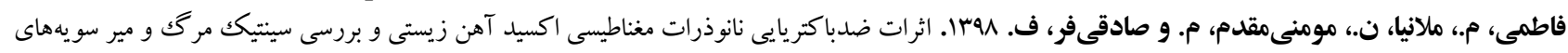

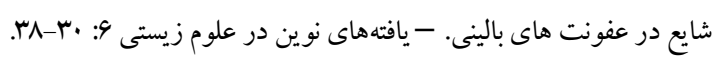

